\title{
Strategic Analysis of Internal, External Factor Evaluation Matrix and Strategic Planning in BTPN bank, Indonesia
}

\author{
Intan Fildzah Wijayati ${ }^{1}$, Ivan Setio ${ }^{2}$ and Sean Marvin Tanupatra ${ }^{3}$ \\ ${ }^{1-2-3}$ Strategic Management \\ Master of Management Department \\ Pelita Harapan University Surabaya Campus \\ Master of Management Department \\ Indonesia
}

\begin{abstract}
In this digital era, business competition is becoming increasingly tight and makes every company must improve the quality of their services. One sector that experienced this was the financial and banking industry. The digital age created new opportunities and new competitors in the financial industry, marked by the emergence of Financial Technology (Fintech), digital payment, cryptocurrencies and even digital banking. The quality of banking services in Indonesia is expected to increase significantly, in order to be able to reach all levels of society and be able to survive in business competition.
\end{abstract}

This study aims to review some of latest efforts to develop conceptual and empirical relationships with business competition strategies internally and externally in the bank's performance. The expected benefit of this research is to add knowledge to business people in developing business strategies to be able to solve problems related to the performance of leaders and strategic teams.

This research is quantitative research. The research method used is a quantitative method based on secondary data. Data collection techniques use documentation study techniques from financial report information and data published by the bank concerned. Written documents can be in the form of annual reports, articles and journals.

The results of the study show the company that developed a strategy and decision-making process based on reliable knowledge of the needs of the community or banking customers, supported by a variety of innovative ideas and creative and risk-taking more likely to make high-quality strategic decisions.

The main recommendation given for the object of this research is that BTPN should sell retirement savings products and services through several digital platforms such as creating application software and collaborating with e-commerce to distribute retirement savings products and services. This is because the online retirement products strategy in this study is the most important for the company.

Key Words: Financial Industry, Banking Services, Digital Banking, Business Strategies, BTPN

\section{INTRODUCTION}

PT. Bank BTPN is a bank that focuses on serving the mass market segment consist of pensioners segment, Micro, Small and Medium enterpreneur segment, namely MSMEs and productive pre-prosperous communities, the consuming class segment and the corporate segment. The business focus is supported by 6 business units owned by Bank BTPN, which are BTPN Purna Baktifocusing on serving pensioners \& pre-retirement customers, BTPN Mitra Usaha Rakyat-focusing on serving micro businesses, BTPN Business Partners-focusing on serving small and medium businesses BTPN Sinaya-focusing on the growth of third party funds from the middle to upper income institutional \& individual segments so that it is the funding business unit. and the last two business units are Jenius \& BTPN Wow! [1].

The consuming class segment through Jenius' digital banking platform is a service innovation for the segment of urban society and following technological developments. Jenius itself is a saving account with Visa debit for retail transactions worldwide. Whereas, the below-consuming class segment is intended for people with lower-middle criteria who have not been touched by 
banking services through BTPN Wow!. The services utilize mobile technology supported by BTPN Wow! as an extension of the bank to reach services to all corners of Indonesia. In addition, the BTPN Bank has a subsidiary, namely BTPN Syariah focusing on serving customers from productive pre-prosperous communities. [2].

In 2018, it was a historic matter for BTPN to merge with PT. Bank Sumitomo Mitsui Indonesia (SMBCI), which is a global corporate bank from Japan. After that, BTPN becomes a complete bank and offers a variety of financial services for all individual customers and business customers in the wider Indonesia. [3].

This merger shows that BTPN is able to compete in the banking sector based on the Financial Services Authority Regulation No. 6/POJK.03/2016 about Business Activities and Office Networks based on Core Capital Banks or Commercial Banks based on Business Activities (BUKU) [4].

Bank BTPN has core capital of Rp 5 trillion - Rp 30 trillion so it is classified as BUKU III, which includes business activities carried out by Bank BUKU 1 and 2. According to Article 18 of the Financial Services Authority Regulation, BUKU III Banks can open Office Networks overseas but limited to the Asian region in conducting business activities. Banks in Indonesia in type BUKU III are Bank ICBC Indonesia, Bank Bukopin, Central Java BPD Bank, and others [5].

In 2015, the BTPN formulated the Jenius application based on digital savvy research in Indonesia and materialized in 2016 by launching a Jenius financial application after the development process for 18 months and the investment spent was Rp. 500 billion. [6].

In this era of advanced technology, BTPN has successfully entered the digital banking market in Indonesia with the Jenius application. Jenius is a digital-based innovation that has the purpose of creating a bank account without the need to come to the bank directly. All activities of various banking transactions are carried out digitally, which makes it easier for customers to manage their finances. As significant developments and advancements, Jenius managed to get public attention for the sophistication of the features and products offered so that the BTPN Bank customers also increased [7].

For the first time, BTPN Bank nominated in the article World's Best Bank 2019 as Top 2 published by Forbes. It was the first time Forbes released World's Best Bank, which assessment is carried out with a customer-centric approach to 40,000 consumers in all parts of the world. Forbes collects customer opinions about banks that they are currently using. This assessment consists of Customer Satisfaction, Customer Trust, Fees, Digital Services, and Financial Information [8].

In this study, the Authors team review some of the latest efforts to develop conceptual and empirical relationships with business competition strategies internally and externally in the Bank's performance. Next, we will also criticize briefly about the efforts to conceptualize business strategy as a problem related to the performance of leaders and strategic teams. Finally, we conclude by offering some thoughts on how future research in this field can be improved and reviewed some unresolved issues for banking executives.

\section{LITERATURE REVIEW}

\subsection{External Factor Evaluation (EFE) \& Internal Factor Evaluation Matrix IFE}

According to [9], External Factor Evaluation (EFE) Matrix is used to evaluate the company's external factors. External data is collected to analyze matters relating to the problem: Economy, social culture, environment, politics, law, technology, competition in industrial markets.

The internal factor matrix is used to find out the company's internal factors related to strengths and weaknesses that are considered important [9].

Internal Factor Evaluation Matrix (IFE) is a strategy formulation tool used to summarize and evaluate key strengths and weaknesses in a functional area of business, and also provides a basis for identifying and evaluating relationships between these areas [10].

External Factor Evaluation (EFE) matrix is used to find out the company's external factors related to opportunities and threats that are considered important. External data is collected to analyze matters concerning economic, social, cultural, demographic, environmental, political, governmental, legal, technological, and competitive issues [10].

According to [11] the summary step in conducting an internal management strategic audit is to build a Matrix Internal Factor Evaluation (IFE). This strategy formulation tool summarizes and evaluates strengths and weaknesses in key business functional areas, and also provides a basis for identifying and evaluating relationships between regions. 
The EFE matrix is a tool that allows strategic planners to summarize and evaluate economic, socio-cultural, environmental, political, governmental, legal, technological and competitive information. This matrix helps managers organize external strategic factors into generally accepted categories of categories about opportunities and threats [12].

According to [13] IFE Matrix (Internal Factor Evaluation) is a matrix that allows strategists to determine whether the strengths and weaknesses possessed by companies that can be seen from marketing, finance, information systems management, operations and production and research and development. According to [13] EFE matrix (External Factor Evaluation) is a matrix that allows strategists to summarize economic, social, cultural, demographic information, environment, politics, government, law, technology, and competitiveness.

\subsection{SPACE}

The SPACE matrix has been used to determine the company's strategic position [14]. The SPACE matrix has been used in other studies in champ management [15].

The Position Evaluation and Strategic Action Matrix or SPACE Matrix is a four quadrant framework that shows whether an organization fits an aggressive, conservative, defensive or competitive strategy [10].

The difference between the two matrices mentioned is that the IFE matrix focuses on strengths and weaknesses (as internal factors) and EFE as opportunities and threats (as external factors) to recommend strategies for organizations but the SPACE matrix focuses on financial strength and competitive advantage (as internal factors) and environmental stability and industrial strength (as external factors) to formulate strategies [16].

According to [17], the matrix of strategic position and evaluation (Strategic Position and Action Evaluation-SPACE) is a stage 2 (two) matching tool. This matrix is a four quadrant framework that shows whether an aggressive, conservative, defensive or competitive strategy is most suitable for a particular organization. [15] states that the matrix of strategic position and action evaluation (SPACE) is a management tool used to analyze a company's business.

SPACE matrix analysis will be very useful for formulating and implementing company goals and objectives. Based on information obtained from SPACE matrix analysis, it is deemed necessary to make changes both in the goals, objectives, policies, and strategies of existing companies [18].

Space matrix includes four positions which are: Aggressive position, conservative position, defensive position, conservative position. Horizontal axis in space graph shows FS (Financial Strength) and CA (Competitive Advantage); vertical axis shows ES (Environmental Stability) and IS (Industrial Strength) [17]. Strategic Position and Action Evaluation Matrix or SPACE Matrix is a four quadrant framework that shows whether an organization fits to aggressive, conservative, defensive, or competitive strategies [10].

SPACE matrix has been used for determining the companies' strategic position [14]. The SPACE matrix has been used in another study in a champ management [15].

\subsection{QSPM}

QSPM is designed to determine its relatives the attractiveness of viable alternative strategies by examining the fundamentals of internal and external factors. Conceptually, the QSPM determines relatives to attract various strategies based on the extent to which alternative strategies will utilize strengths and opportunities, correct weaknesses, and avoid or reduce threats [19].

To do the required data analysis, the main factors of QSPM come from the IFE Matrix and EFE Matrix and the alternative SWOT Matrix strategies. However, not all alternative strategies must be evaluated using QSPM. Researchers must use good intuitive assessments to choose which strategies to analyze using QSPM [20].

According to [9], QSPM is a technique that can objectively establish priority strategies that are prioritized. This method is a recommended tool for strategists to objectively evaluate alternative strategy choices, based on the internal - external success key factors identified earlier.

QSPM evaluates the relative attractiveness of some alternative strategic choices objectively [21]. The advantage of using the QSPM matrix is that strategies can be examined sequentially and simultaneously, and there is no limit to the number of strategies that can be evaluated at once [22]. QSPM is used to determine alternative strategies generated in the IFE \& EFE matrix [23].

QSPM is a recommended tool for strategists to evaluate the choice of strategies to objectively evaluate alternative strategy choices, based on internal key success factors that have been identified previously [24].

\section{RESEARCH METHOD}


The instrument in this study uses secondary data. After the focus of the research becomes clear, a simple research instrument will be developed, which is expected to be able to complete the data and compare the data that has been found previously [25].

Data collection techniques will use documentation study. Documentation Study Technique is to collect and explore financial report information and data published by the Bank concerned. The written documents are in the form of: news, annual reports, articles and journals. The data used in this research is secondary data. Secondary data is data obtained indirectly, that is, there is an intermediary media (obtained, recorded or released by another party).

Analysis of data processed using IFE and EFE (the input and matching stage), SPACE (decision stage) and QSPM (decision stage). Final stage of decision was made by QSPM.

\section{RESEARCH FINDINGS}

The total results of Internal Factor Evaluation are 3.23. This shows that BTPN is strong internally even though it still has weaknesses that are generally caused by changes in digitalization and corporate restructuring.

Table 4.1. Internal Factor Evaluation (IFE) Matrix

\begin{tabular}{|c|c|c|c|}
\hline Key Factors & Weight & Ratings & Weighted Scores \\
\hline \multicolumn{4}{|c|}{ Strengths } \\
\hline Bank Merger & 0.20 & 4 & 0.80 \\
\hline Assets \& Equity Growth & 0.22 & 3 & 0.66 \\
\hline Digital Banking Platform & 0.12 & 5 & 0.60 \\
\hline Market Leader in Pensioner Loans & 0.05 & 5 & 0.25 \\
\hline Effectively Promotion & 0.1 & 4 & 0.40 \\
\hline \multicolumn{4}{|c|}{ Weaknesses } \\
\hline Unstable System \& Products & 0.12 & 2 & 0.24 \\
\hline Third Party Marketing Strategy & 0.10 & 1 & 0.10 \\
\hline Lack of Branch Offices \& ATM Machines & 0.09 & 2 & 0.18 \\
\hline Total & 1 & & 3.23 \\
\hline
\end{tabular}

The total External Factor Evaluation result is 3.20. This shows that the BTPN is able to take advantage of opportunities to minimize threats in the Fintech trend by creating new products and services through existing platforms such as Jenius in digitizing and the corporate structuring process.

Table 4.2. External Factor Evaluation (EFE) Matrix

\begin{tabular}{|l|c|c|c|}
\hline \multicolumn{1}{|c|}{ Key Factors } & Weight & Ratings & Weighted Scores \\
\hline \multicolumn{3}{|c|}{ Opportunities } \\
\hline Bank BUKU 4 & 0.10 & 3 & 0.30 \\
\hline New Segment & 0.20 & 4 & 0.80 \\
\hline New Products and Services & 0.25 & 5 & 1.25 \\
\hline
\end{tabular}


International Journal of Advances in Scientific Research and Engineering (ijasre), Vol 5 (4), April-2019

\begin{tabular}{|c|c|c|c|}
\hline \multicolumn{4}{|c|}{ Threats } \\
\hline Market Leading Competitors & 0.10 & 2 & 0.20 \\
\hline Lack of Education in Digital Banking & 0.15 & 3 & 0.45 \\
\hline FinTech Domination & 0.2 & 1 & 0.20 \\
\hline Total & 1 & & 3.20 \\
\hline
\end{tabular}

4.3.1 FINANCIAL STRENGTH

\begin{tabular}{|c|c|c|c|}
\hline \multicolumn{2}{|c|}{ EXTERNAL STRATEGIC POSITION } & \multicolumn{2}{|c|}{ INTERNAL STRATEGIC POSITION } \\
\hline Environmental Stability (ES) & Score & Financial Strength (FS) & Score \\
\hline 1. Technological Changes & -5 & 1. CAR & +5 \\
\hline 2. Inflation & -3 & 2. $\mathrm{BOPO}$ & +4 \\
\hline 3. Competitors Variation & -2 & 3. ROA & +4 \\
\hline Products & & 4. LDR & +3 \\
\hline 4. Barriers to Entry & -2 & 5. Net \& Gross NPL & +2 \\
\hline Total & -12 & & 20 \\
\hline Total Average & $\begin{array}{r}-12 / 4= \\
-3\end{array}$ & & $\begin{array}{r}20 / 6= \\
\mathbf{3 , 3 3}\end{array}$ \\
\hline Industry Strength (IS) & & Competitive Advantage (CA) & \\
\hline 1. Growth Potential & +4 & 1. Market Share & -2 \\
\hline 2. Resource Availability & +3 & Quality & -4 \\
\hline 3. Technological Advantage & +4 & 3. High Distribution Quality & -5 \\
\hline & & 4. Customer Loyalty & -2 \\
\hline Total & 11 & & -13 \\
\hline Total Average & $11 / 3=\mathbf{3 , 6 7}$ & & $\begin{array}{r}-13 / 4= \\
-\mathbf{3 . 2 5}\end{array}$ \\
\hline
\end{tabular}

Table 4.3. Strategic Position Action \& Evaluation (SPACE) Matrix

In this dimension, the factors that influence the achievement of the efficiency of the Bank's banking sector include the ratio of

Operating Costs to Operating Income and the Net Interest Margin (NIM) ratio (Article 21 Regulation of the Financial Services Authority Number 6 / Pojk.03/2016 concerning Activities Business and Office Network Based on Bank Core Capital) and according to Muljawan et al. (2014) explain the factors that affect the operational efficiency of banks in Indonesia including total assets as a proxy of bank size, Return on Assets (ROA) as a proxy for bank profits, Capital Adequacy Ratio (CAR) and Loan to Deposit Ratio (LDR). as a proxy for bank liquidity, Non Performing Loans (NPL) as a proxy for bank credit risk, real GDP growth, JCI (Composite Stock Price Index), and the rupiah exchange rate against the dollar.

Capital Adequacy Ratio that shows the ability of banks to provide funds that are used to overcome the possible risk of losses. This ratio is important because by keeping the CAR at a safe limit (minimum 8\%), it also protects customers and maintains overall financial system stability. The greater the value of CAR reflects the better banking ability in facing the possibility of risk of loss. December 31, 2018 and 2017, the consolidated capital adequacy ratio for the Bank and Subsidiaries is 25.26\% and 24.64\%, respectively [26].

Operational Expenses Against Operational Income is a ratio that describes banking efficiency in carrying out its activities. Operational expenditure is the interest expense given to customers while operating income is interest earned from customers. The smaller the Operating Cost to Operating Income value means the more efficient the bank is in operation. Data at the BTPN Annual Report stated that 2017 experienced a decrease of $86.5 \%$ to $79.2 \%$ in 2018 . This shows that BTPN was able to maintain the efficiency of the company Factors that made banks' Operating Cost to Operating Income ratios shrink as banks began to lead 
digitization until efficiency improves. In addition, banks began to reduce reserve costs because the quality of credit improved so that operational costs dropped [27].

Return On Assets is a ratio that measures a bank's ability to generate profit or profit (can be called profitability) by comparing net income with resources or total assets owned. Its function is to see how effective banks are in using their assets in generating income. The greater the value of ROA means the better the ability of banks to generate profits. In 2017 it is $2.1 \%$ and has increased to $3.1 \%$ [27].

Loan to Deposit Ratio is a ratio that measures the ability of banks to meet short-term liabilities (can be called liquidity) by dividing total credit against total Third Party Funds (TPF). Banking liquidity needs to be managed to meet the needs when customers take their funds and distribute loans (loans) to borrowers (debtors). If the LDR value is too high, it means that banks do not have sufficient liquidity to cover their obligations to customers (DPK). Conversely, if the value of LDR is too low, it means that banks have sufficient liquidity but their income may be lower, because as is known in the world of banking to obtain income through loans distributed. The value of 2017 \& 2018 is relatively the same, namely $96.2 \%$. This shows that the better because the lower limit is in accordance with BI regulations, which is $80 \%$. If it reaches a number or is below it, it can endanger the Bank [27].

Non Performing Loans (Net \& Gross) that means credit growth is carried out carefully, as reflected in the low level of nonperforming loans (NPLs) of $1.2 \%$ (gross) and $0.5 \%$ (net ) This ratio reflects BTPN's expansionary strategy which still pays attention to the principle of prudence. The year 2018 is indeed a tough year. All business sectors experienced weakness. This has an impact on debtor payments. Finally causing the NPL to increase. NPL - gross $1.2 \%$ (2018) $0.9 \%$ (2017) \& NPL - net $0.5 \%$ (2018) $0.4 \%$ (2017) [28].

Net Interest Margin is experience a decrease in net interest margin from 11.6\% in 2017 to $11.3 \%$ in 2018. All bank NIMs in 2018 fell compared to 2017. There is a connection with the weakening of all economic sectors causing NPLs to rise so asset volumes are difficult to rise. Finally, BTPN tried to reduce interest to increase assets [27].

\subsubsection{COMPETITIVE ADVANTAGE}

Currently Market share in 2019, the number of Jenius customers has increased to 1.2 million customers in Indonesia and has experienced a significant increase in terms of total company assets [29].

Quality through this digital transformation, the customer service network has expanded and the quality of customer service has been maintained even though the number of branch offices has decreased and the organization has become leaner. This transformation step will continue until the end of 2018. As for developing the quality of digital services, throughout 2017, BTPN has invested Rp 832 billion, an increase of 36\% compared to the investment value in 2016 of Rp 611 billion [30].

Jenius application allows you to send money and pay bills using account numbers, $\$$ cashtag, telephone numbers, or even e-mail addresses \& can make bill payments, such as credit cards, telephone, water, TV, and internet. Top-up GoPay, e-money, T-Cash, free interbank transfer fees (there is a current quota), there is a cashback, top up refund fee balance, min. 500,000 every Monday, requesting a debit card on demand, an interest rate of $5 \%$ in Flexi Saver, $\mathrm{x}$-Card such as CC, so you can pay recurring billing and others [31].

BTPN Mitra Usaha Rakyat (MUR) - Launched in 2009 to serve micro customers with loan ceilings starting at 20 million Rupiah. As a form of seriousness in serving this segment, in the first year of operation, management built a MUR network of more than 600 units throughout Indonesia.

BTPN Purna Bakti - Rebranding of the retired business to become BTPN Purna Bakti, which was developed and designed specifically to answer the needs of customers who have and will enter the retirement period. A new safe and comfortable service office, equipped with free medical check-up facilities, religious facilities, and a community center for social activities.

BTPN Mitra Bisnis - Since serving micro customers, management sees this segment growing so that its needs are increasingly complex. To accommodate this development, BTPN launched Business Partners in 2013. In addition to serving MUR customers who are going up in class, this unit also targets a broader customer segment in small and medium businesses.

BTPN Tunas Usaha Rakyat (TUR) - Another innovation in the micro-finance business is to enter the lower segment of productive poor communities with funding of Rp2 million per customer. This segment is served through BTPN Tunas Usaha Rakyat under the management of the Sharia Business Unit (UUS) since 2011.

Towards change in the era of the 4th industrial revolution and digital disruption, in the last 5 years BTPN has again innovated by creating 2 digital banking platforms for two different segments:

BTPN Wow! - BTPN is a pioneer in the 'Laku Pandai' program initiated by the Financial Services Authority (OJK) by launching BTPN Wow! in 2015. This business unit provides banking services to the mass market by utilizing cellular phones and supported by agent services.

Jenius - Through the launch of Jenius in 2016, BTPN introduced a revolution in the banking sector with a digitalization process that began early. Jenius is a digital banking platform that focuses on targeting the consuming class segment. 
BTPN's High Distribution Quality also rolled out the transformation agenda of integrating digital technology into BTPN's core business and its distribution network. There are four initiatives being rolled out; digitalization, centralization, migration to digital channels and branch integration while maintaining the concept of customer centricity as the main foundation.

BTPN's Customer Loyalty operates a customer loyalty program, which is specific to SME business (business partners) BTPN has a name that is customer fellow. So the relationship between the bank and the debtor is not as usual. BTPN's mission is to succeed the customer's business. So it is more active as a consultant for customers [32].

\subsubsection{ENVIRONMENTAL STABILITY}

Technological Changes in BTPN's environment Digital-based systems or applications offered by banks are relatively the same, but what distinguishes them from other banks is that BTPN dares to take innovative steps in Jenius according to developments or trends in society so that they become one of the leading the technology [33].

In February 2019 inflation rate according to Bank Indonesia data recorded at $2.57 \%$, this inflation rate is still relatively low and the results of a Bank Indonesia (BI) survey show the inflation rate in the first week of March 2019 reached $0.07 \%$ monthly or month to month (mtm), or $2.44 \%$ on an annual basis or year on year (yoy). According to the BI survey, this inflation was driven by prices of several commodities ranging from shallots and garlic, to air freight rates. Meanwhile, the government and BI have targeted inflation this year to be in the range of $2.5 \%$ to $4.5 \%$, or the same as last year's target. In 2018, inflation can reach $3.13 \%$ or below the target's midpoint. This inflation was also achieved amid the volatility of the rupiah exchange rate in 2018 [34].

Competitor Variation Products data in BTPN and Danamon Annual Reports, it is seen that the two offered are the same, namely in terms of funding \& lending and each bank policy is also different in managing its products but Danamon has more product variations and has more partners than BTPN. [35 \& 36]

Of course there are obstacles to entering the market, BTPN is a digital pioneer with users reaching 1.2 million digital customers since the launch two years ago until now. However, the transactional bank that is in the process is that there are many competitors who have long been in BUKU III and have far more customers than BTPN. After having merged power, the things

done by BTPN were developing a post-merger strategy to compete more with other banks, Bank ICBC Indonesia, Bank Bukopin, Central Java BPD Bank, KEB Hana Indonesia Bank, Bank Mayapada, Bank BPD Jatim, Bank Syariah Mandiri, Bank ANZ Indonesia, Bank DKI, Bank DBS Indonesia, West Java and Banten BPD Bank, Mizuho Bank Indonesia, Bank Sumitomo Mitsui, Bank UOB Indonesia, Bank Mega, Bank HSBC Indonesia, Bank Permata, Bank Maybank Indonesia, Bank BTN, Bank OCBC NISP, Bank Danamon \& Bank Panin [37].

\subsubsection{INDUSTRY STRENGTH}

BTPN's growth potential has experienced a very high increase from 2017 to 2018. Data is in the annual report. Therefore, it was concluded that BTPN still needed to improve in the transformation from non-transitional to transactional. The data shows that in fact BTPN was able to compete with the Bank in the same segment [35, 36 \& 38].

Table 4.3.3.1 Growth Potential 2017 \& 2018

\begin{tabular}{|c|c|c|c|c|c|c|}
\hline \multicolumn{3}{|c|}{2017} & \multicolumn{3}{c|}{$\mathbf{2 0 1 8}$} & FS \\
\hline BTPN & MEGA & DANAMON & BTPN & MEGA & DANAMON & \\
\hline & & & $25,3 \%$ & $22,79 \%$ & $22,2 \%$ & CAR \\
\hline $86,5 \%$ & $81,28 \%$ & $72,1 \%$ & $79,2 \%$ & $77,78 \%$ & $70,8 \%$ & BOPO \\
\hline $2,1 \%$ & $2,24 \%$ & $3,1 \%$ & $3,1 \%$ & $2,47 \%$ & $3,1 \%$ & ROA \\
\hline $96,2 \%$ & $56,47 \%$ & $93,3 \%$ & $96,2 \%$ & $67,23 \%$ & $95,0 \%$ & LDR \\
\hline $0,4 \%$ & $1,41 \%$ & $1,8 \%$ & $0,5 \%$ & $1,27 \%$ & $1,9 \%$ & NPL NET \\
\hline $0,9 \%$ & $1,60 \%$ & $2,8 \%$ & $1,2 \%$ & $2,01 \%$ & $2,7 \%$ & NPL \\
& & & & & & GROSS \\
\hline $11,6 \%$ & $5,80 \%$ & $9,3 \%$ & $11,3 \%$ & $5,19 \%$ & $8,9 \%$ & NIM \\
\hline
\end{tabular}

Existing resources avaialbility in the Bank in performing the best service standards through branch offices, facilities, machinery \& HR. However, due to data limitations there are only branch offices \& number of employees. The number of 
International Journal of Advances in Scientific Research and Engineering (ijasre), Vol 5 (4), April-2019

employees of PT Bank Tabungan Pensiunan Nasional and Subsidiaries ("Banks and Subsidiaries") as of December 31,2018 and 2017, were 19,175 and 20,912 employees, respectively (unaudited) [35] and PT. Bank Danamon's number of employees 12,442 (2018) \& 16,811 (2017) [36].

Table 4.3.3.2 Resources Availibility of Bank BTPN

\begin{tabular}{|c|c|c|c|c|c|c|c|}
\hline Offices & Headquarters & $\begin{array}{c}\text { Purna Bakti } \\
\text { (Product) }\end{array}$ & $\begin{array}{c}\text { Sinaya } \\
\text { (Product) }\end{array}$ & $\begin{array}{c}\text { MUR } \\
\text { (Product) }\end{array}$ & $\begin{array}{c}\text { I-SME } \\
\text { (Product) }\end{array}$ & $\begin{array}{c}\text { SDB } \\
\text { (Product) }\end{array}$ & Total \\
\hline Headquarters & 2 & 0 & 0 & 0 & 0 & 0 & 2 \\
\hline $\begin{array}{c}\text { Regional } \\
\text { Office }\end{array}$ & 0 & 9 & 0 & 0 & 0 & 0 & 9 \\
\hline $\begin{array}{l}\text { Branch } \\
\text { Office }\end{array}$ & 0 & 50 & 7 & 4 & 0 & 0 & 61 \\
\hline Cash Office & 0 & 166 & 33 & 92 & 4 & 1 & 296 \\
\hline $\begin{array}{l}\text { Operational } \\
\text { Functional } \\
\text { Office }\end{array}$ & 0 & 0 & 0 & 0 & 0 & 0 & $\mathbf{0}$ \\
\hline $\begin{array}{c}\text { Non } \\
\text { Operational } \\
\text { Functional } \\
\text { Office }\end{array}$ & 0 & 0 & 0 & 41 & 0 & 0 & 41 \\
\hline $\begin{array}{l}\text { Payment } \\
\text { Point }\end{array}$ & 0 & 318 & 0 & 0 & 1 & 3 & $\mathbf{0}$ \\
\hline ATM & 0 & 144 & 67 & 0 & 0 & 0 & 318 \\
\hline TCR & 0 & 0 & 0 & 0 & 0 & 1 & 215 \\
\hline Total & 2 & 687 & 107 & 137 & 5 & 5 & 943 \\
\hline
\end{tabular}

Table 4.3.3.3 Resources Availibility of Bank Danamon

\begin{tabular}{|c|c|}
\hline Offices & Total \\
\hline Conventional Main Branch Office & 42 \\
\hline $\begin{array}{c}\text { Conventional Sub-Branch Offices \& } \\
\text { Danamon Savings and Loans }\end{array}$ & 651 \\
\hline $\begin{array}{c}\text { Main Branch Office and Sharia Sub- } \\
\text { Branch Office }\end{array}$ & 10 \\
\hline ATM & 1.431 \\
\hline
\end{tabular}

BUKU III and IV with large capital will make fintech their own bank version. Technological advantage in BTPN is \$ 182.3 million in funding announced for fintech startups this year, 57\% related to the lending subsector. a study that showed that the contribution of fintech lending to 21 business sectors in Indonesia was IDR 26 trillion. For the financial services sector, for example, fintech claimed to contribute IDR 7.4 trillion [39].

Based on the results in Space Matrices BTPN is on Aggressive quadran category could take advantage of opportunities and overcome weaknesses in the following ways. First, Intensive strategy that BTPN must socialize the importance of having retirement savings, ease of digital marketing, and provide financial education through social media and workshops in big and small cities in Indonesia. Second, Integration strategy that BTPN should collaborate with Fintech so that the Fintech function does not replace banking but is complimentary. Jenius, product from BTPN include the market leader and only have one competitor, DBS. By having collaboration with Fintech, merchants, and events, BTPN can maintain its existence in the Digital Banking market compared to Bank Danamon \& Bank Mega. 


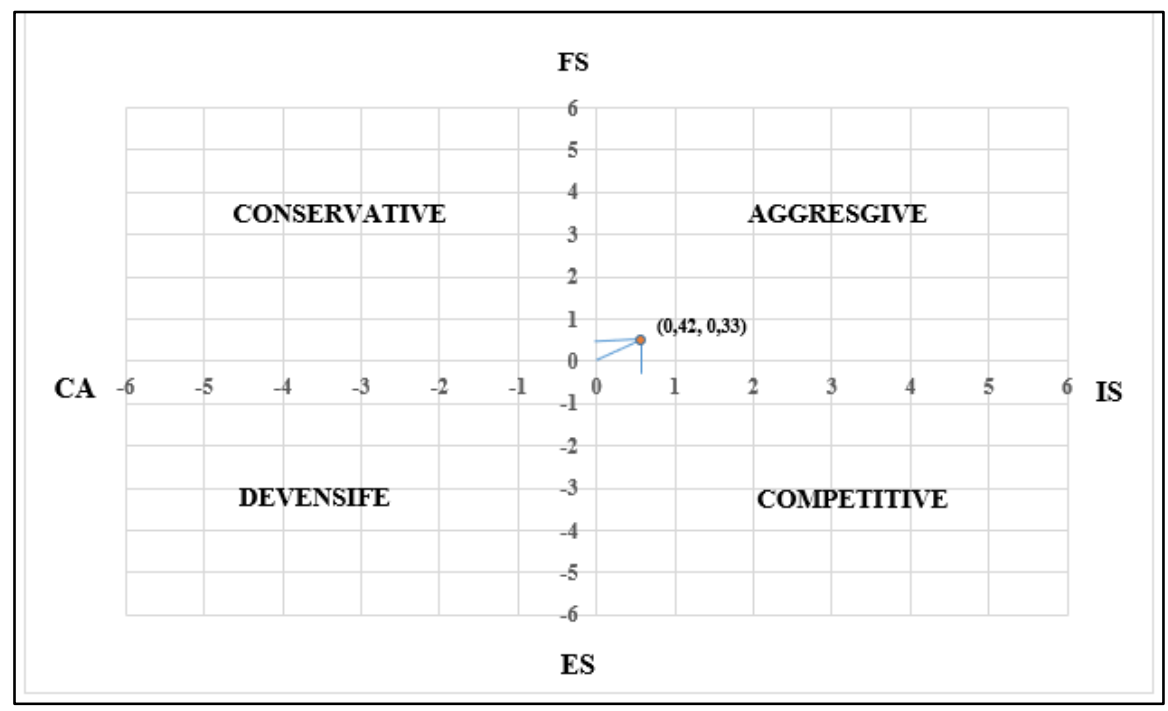

Figure 4.3.3. : Quadran of Strategic Position Action \& Evaluation Matrix (SPACE)

Directional Vector Coordinates

X-axis: IS $(3,67)+$ CA $(-3,25)=0,42$

\begin{tabular}{|l|c|c|c|}
\hline \multirow{2}{*}{ QSPM Matrix } & \multicolumn{3}{|c|}{ Strategic Alternatives } \\
\cline { 2 - 4 } & $\begin{array}{c}\text { Collaboration } \\
\text { with Fintech }\end{array}$ & $\begin{array}{c}\text { Retirement Products } \\
\text { Online }\end{array}$ & $\begin{array}{c}\text { Financial } \\
\text { Education }\end{array}$ \\
\hline
\end{tabular}

Y-axis: $\operatorname{ES}(-3)+F S(3,33)=0,33$

Table 4.4. Quantitative Strategic Planning Matrix 
International Journal of Advances in Scientific Research and Engineering (ijasre), Vol 5 (4), April-2019

\begin{tabular}{|c|c|c|c|c|c|c|c|}
\hline Key Factors & Weight & AS & TAS & $\mathbf{A S}$ & TAS & $\mathbf{A S}$ & TAS \\
\hline Bank Merger & 0,20 & & & & & & \\
\hline Assets \& Equity Growth & 0,05 & 4 & 0.88 & 4 & 0.88 & 4 & 0.88 \\
\hline Digital Banking Platform & 0,25 & 5 & 0.60 & 5 & 0.60 & 4 & 0.48 \\
\hline Market Leader In Pensioner Loans & 0,10 & 4 & 0.20 & 4 & 0.20 & 5 & 0.25 \\
\hline Effectively Promotion & 0,15 & 5 & 0.50 & 4 & 0.40 & 5 & 0.50 \\
\hline Unstable System And Products & 0,03 & 1 & 0.12 & 1 & 0.12 & & \\
\hline Third Party Marketing Strategy & 0,12 & 3 & 0.30 & 2 & 0.20 & 4 & 0.40 \\
\hline $\begin{array}{l}\text { Lack Of Branch Offices And ATM } \\
\text { Machines }\end{array}$ & 0,10 & 3 & 0.27 & 3 & 0.27 & & \\
\hline Bank BUKU 4 & 0,10 & & & 5 & 0.50 & & \\
\hline New Segments & 0,15 & 4 & 0.80 & 5 & 1.00 & 5 & 1.00 \\
\hline New Products And Services & 0,25 & 4 & 1.00 & 4 & 1.00 & 4 & 1.00 \\
\hline Market Leading Competitor & 0,15 & 3 & 0.30 & 2 & 0.20 & 3 & 0.30 \\
\hline Lack Of Education In Digital Banking & 0,15 & 3 & 0.45 & 1 & 015 & 4 & 0.60 \\
\hline Fintech Domination & 0,20 & & & & & & \\
\hline TOTAL & & & 5.42 & & 5.52 & & 5.41 \\
\hline
\end{tabular}

From the results of the QSPM matrix calculation above, the following results are obtained:

- Strategy 1 (Retirement Products Online) gets a value of 5.52 that means BTPN can sell pension products and services through several platforms can be an option for companies to expand and become more widely known by the community.

-Strategy 2 (Collaboration with Fintech) gets a value of 5.42 that means a strategy that can be applied when the Fintech competition market begins to grow in Indonesia. BTPN must implement a strategy that can make banking services the parent application to manage financial e-payments

- Strategy 3 (Financial Education) gets a value of 5.41 that means a strategy that must be immediately implemented by BTPN to socialize the importance of managing finance, the digital savings function, and the importance of managing pension funds since youth. By utilizing social media, Jenius Connect from BTPN can be the community's first choice for managing their finances.

\section{CONCLUSION}

Continuous efforts to develop rigorous and empirically supported conceptual relationships between strategic management and competitive strategies are commendable. One of the most relevant conclusions from this brief review is that the process strategy used in strategic decision making is very important for the effectiveness \& efficiency of the Bank. Companies that develop strategies and decision-making processes based on reliable knowledge of the needs of the community or banking customers, supported by a variety of innovative ideas as well as creative and risk-taking are more likely to make high-quality strategic decisions. Combining this decision-making process with the pro-stakeholder culture and advances in digital-based technology can increase the recognition of opportunities in areas not yet reached by the Bank despite the restructuring problem, namely the change to a transactional Bank but BTPN is able to position as BUKU III Bank with the existence of these strategies so that companies that focus on business strategies can improve their performance.

Recommendation from the results of this study are to sell retirement products and services through several digital platforms such as creating their own application software, and collaborating with various e-commerce to distribute products and services. At present, several companies have implemented this strategy such as mutual funds and gold savings. Some companies have created application software for iOS and Android so customers can register, pay and monitor the progress of their investment value through the application. In addition, other companies also collaborate with e-commerce by creating new categories to invest through e-commerce applications directly. Customers get the convenience of registering, paying bills through the application and getting lots of cashback promos and bonuses held by e-commerce every month. BTPN should implement this strategy by creating a special application for retirement savings so the customers can access data and monitor the progress of their investment amount. 
In addition, BTPN should collaborate with e-commerce to present retirement savings services through e-commerce applications directly and provide easy payments, promos and bonuses.

\section{REFERENCES}

1. Btpn official wesite, Retrieved April 7, 2019, from https://www.btpn.com/.

2. Fokus Pada Inovasi Investasi BTPN Bertumbuh 77\%. (2017, October 24). Retrieved April 7, 2019, from https://www.btpn.com/id/berita-media/siaran-pers?content=12585\&active=archive \&page $=1$

3. Alasan Di Balik Proses Mergernya BTPN Dan SMBCI. (2018, January 29). Retrieved April 7, 2019, from https://www.cnbcindonesia.com/market/20180129132701-17-2795/alasan-di-balik-proses-mergernya-btpn-dan-smbci

4. Peraturan Otoritas Jasa Keuangan Nomor 6/Pojk.03/2016 Tentang Kegiatan Usaha Dan Jaringan Kantor Berdasarkan Modal Inti Bank : Indonesia, 2016.

5. Bank Apa yang Termasuk Kategori BUKU 3?. Retrieved April 7, 2019, from https://www.simulasikredit.com/bank-apayang-termasuk-kategori-buku-3/

6. Luncurkan Jenius, BTPN Investasi Rp500 Miliar. (2016, August 11). Retrieved April 7, 2019, from http://infobanknews.com/luncurkan-jenius-btpn-investasi-rp500-miliar/

7. 2 Tahun Diluncurkan, Jenius BTPN Punya 1,2 juta Pengguna. (2019, February 22). Retrieved April 7, 2019, from https://www.cnbcindonesia.com/fintech/20190222151100-37-57133/2-tahun-diluncurkan-jenius-btpn-punya-12-jutapengguna

8. The World's Best Banks 2019.(2018, February 28). Retrieved April 7, 2019, https://www.forbes.com/worlds-bestbanks/\#6247ea1d1295

9. Sedarmayanti, Manajemen Strategi, Cetakan Kesatu. Refika Aditama, Bandung, 2014.

10. F. R. David, Strategic Management, New Jersey: Prentice Hall, 2009.

11. David, Fred., Strategic management, concepts and cases. $13^{\text {th }}$ ed., Florence, South Carolina: Prentice Hall, 2011.

12. David, Fred R., Strategic Management (Manajemen Strategis Konsep). Publisher: Salemba Empat. Jakarta, 2012.

13. David, F. R., Strategic Management. $14^{\text {th }}$ ed., Florence, South Carolina. Pearson, 2013.

14. Hajkarimi, Abassali, Ahmadi, Mohammad, Baha aldin. Babak, Hajkarimi, Mohammah Hasan, Strategic position and action evaluation matrix used in terms of competition (Case study: construction companies Tehran), Third International strategic management conference, 2009.

15. Ommani, Ahmad Reza, Strength, Weaknesses, opportunities and threats (SWOT) analysis for farming system businesses management: Case of wheat farmers of Shadervan district, shoushtar Township, Iran, African journal of business management, 2001.

16. David, F. R., .Strategic management concepts and cases: A competitive advantage approach, $13^{\text {th }}$ ed., New Jersey: Pearson Education Prentice Hall, 2011.

17. Michael R. Porter, Fred R. David, and Wheelen-Hunger., Strategic Management in Action: Konsep, Teori, dan Teknik Menganalisis Manajemen Strategis Strategic Business Unit Berdasarkan Konsep. 1st ed., Jakarta: Gramedia Pustaka Utama, 2015.

18. Zimmerer T.W., Scarborough, N.M., \& Wilson, D., Essentials of entrepreneurship and small business management. th ed., NJ: Prentice Hall, 2008.

19. David, M. E., David, F. R. \& David, F. R., The quantitative strategic planning matrix: a new marketing tool. Journal of Strategic Marketing, 25(4), 2017, pp. 342-352

20. Ariendi, G. T., Daryanto, A. \& Sanim, B., Strategy for Increasing Business Competitiveness of Green Property. International Journal of Innovation and Scientific Research, 19(1), 2015, pp. 24-32

21. Bhandari, A and RP Verma, Strategic Management: A Conceptual Framework. New Delhi: McGraw Hill Education, 2013.

22. Zulkarnaen, H. O., and Sutopo. Analisis Strategi Pemasaran pada Usaha Kecil Menengah (UKM) Makanan Ringan (Studi Penelitian UKM Snack Barokah di Solo). Diponegoro Journal of Management., 2013, 2(3): 1- 13.

23. David, M. E., David, F. R., \& David, F. R., the Quantitative Strategic Planning Matrix (Qspm) Applied to a Retail Computer Store. The Coastal Business Journal, 2009, 8(1), 42-52.

24. Umar, Husein. (2001). Strategic Management in Action: Konsep, Teori, dan Teknik Menganalisis Manajemen Strategis Strategic Business Unit Berdasarkan Konsep, 2001.

25. S., \& A. R., Meta Analisis Pengaruh Pembelajaran Pendekatan Taktik (Tgfu) Terhadap Pengembangan Aspek Kognitif Siswa Dalam Pendidikan Jasmani. Jurnal Pendidikan Jasmani Indonesia,8, 2nd ser., 2011, pp. 149-150

26. PT. Bank BTPN Annual Report, 2018, p.407.

27. PT. Bank BTPN Annual Report, 2018, p.14.

28. PT. Bank BTPN Annual Report, 2018, p.78. 
International Journal of Advances in Scientific Research and Engineering (ijasre), Vol 5 (4), April-2019

29. Lewat Jenius, BTPN Gaet 1,2 Juta Nasabah Melek Digital. (2019, February 26). Retrieved April 7, 2019, from https://www.inews.id/finance/bisnis/lewat-jenius-btpn-gaet-12-juta-nasabah-melek-digital/471345

30. BTPN Rogoh Kocek Dalam untuk Restrukturisasi Organisasi. (2018, April 16). Retrieved April 7, 2019, from https://www.btpn.com/id/berita-media/ulasan-khusus?content=16552

31. Jenius Pay. Retrieved April 7, 2019, from https://www.jenius.com/app/pay/jenius-pay/

32. Lebih Efisien, Laba BTPN Tumbuh 19\%. (2018, October 19). Retrieved April 7, 2019, from https://www.btpn.com/id/berita-media/siaran-pers?content=18435\&active=archive \&page $=1$

33. Jenius Bank BTPN vs Digibank by DBS, Mana Yang Lebih Unggul?(2018, May 15). Retrieved April 7, 2019, from https://www.moneysmart.id/jenius-bank-btpn-vs-digibank-by-dbs-mana-yang-lebih-unggul/

34. BI Proyeksikan Inflasi Pekan Pertama Maret 0,07\%. (2019, March 08). Retrieved April 7, 2019, from https://katadata.co.id/berita/2019/03/08/bi-inflasi-pekan-pertama-maret-007-inflasi-2019- targeted- 35

35. PT. Bank BTPN Annual Report, 2018.

36. PT. Bank Danamon, 2018.

37. Udah Tahu Belum Apa Itu Jenis Bank BUKU 1, 2, 3, Dan 4? Ini Dia Penjelasannya. (2018, November 4). Retrieved April 7, 2019, from https://www.moneysmart.id/jenis-jenis-bank-apa-itu-bank-buku-1-2-3-dan-4/

38. PT. Bank Mega, 2018.

39. Prospek Bisnis Digital 2019. (n.d.). Retrieved April 7, 2019, from https://katadata.co.id/berita/2018/12/31/prospek-bisnisdigital-2019primadonanya-masih-e-commerce-dan-fintech 